УДК 631.95

(C) 2017

Тогачинська О. В., кандидат сільськогосподарських наук

Національний університет харчових технологій

Тимощук Т. М., кандидат сільськогосподарських наук

Житомирський національний агроекологічний університет

\title{
ОЦІНКА ТЕХНОЛОГІЙ ВИРОЩУВАННЯ ПШЕНИЦІ ОЗИМОЇ ЗА ЕКОЛОГО-АГРОХІМІЧНИМИ ПОКАЗНИКАМИ ТЕМНО-СІРОГО ОПІДЗОЛЕНОГО ГРУНТУ
}

\section{Рецензент - кандидат сільськогосподарських наук І. В. Паращенко}

Викладено результати екологічної експертизи технологій вирощування пшениці озимої в північному Лісостепу за показниками родючості $i$ за впливом на прочеси міграції важких металів у генетичних горизонтах темно-сірого опідзоленого трунту. За результатами екологічного оцінювання встановлено, щзо для впровадження технологій у виробництво, потрібно вдосконалювати деякі технологічні операщії.

Ключові слова: пшениця озима, екологічна оцінка, агрохімічні, санітарно-гігієнічні показники, темно-сірий опідзолений трунт.

Постановка проблеми. Використання агрохімікатів в агроекосистемі є важливою умовою розвитку сучасного землеробства. Однак порушення наукових основ застосування мінеральних і органічних добрив в агроценозі може призвести до незбалансованого живлення сільськогосподарських культур, до зниження поживної цінності рослинної продукції та погіршення стану довкілля.

Науково доведено, що система удобрення повинна забезпечити високу врожайність культур 3 оптимальними показниками якості, збереження i підвищення родючості грунтів за відповідних норматив екологічної безпеки [1]. До складу добрив входять важкі метали, які потенційно здатні забруднювати грунт, змінювати мікробіологічну i біологічну його активність, мігрувати у грунтові води, переміщуватись у рослини і негативно впливати на якість сільськогосподарської продукції $[3,7]$.

У зв'язку з цим, проведення екологічної експертизи технологій вирощування озимої пшениці за основними показниками родючості, а також міграції важких металів у генетичних горизонтах темно-сірого опідзоленого грунту $є$ актуальним питанням.

Аналіз останніх досліджень і публікацій, у яких започатковано розв'язання проблеми. Основними принципами екологічної експертизи технологій вирощування сільськогосподарських культур повинно бути гарантування безпечного для життя та здоров'я людей навколишнього природного середовища, збалансованість екологічних, економічних, медико-біологічних і соціальних інтересів, наукова обгрунтованість, превентивність $[4,5]$.

Сучасні технології вирощування пшениці можуть негативно впливати на технологічні, біохімічні та гігієнічні показники якості зерна, а також призводити до забруднення грунту та суміжних середовищ шкідливими речовинами, знижувати його біологічну активність, сприяти активізації хімічних речовин у грунтові води тощо $[4,5]$.

Метою досліджень було вивчити вплив агротехнологій вирощування пшениці озимої сорту Лада Одеська на вміст рухомих форм важких металів у грунті та проведення екологічного оцінювання технологій вирощування пшениці озимої за показниками родючості грунту і міграції важких металів у генетичних горизонтах темносірого опідзоленого грунту.

Методика проведення дослідження. Дослідження проводили в Інституті агроекології i природокористування НААН 3 озимою пшеницею сорту Лада Одеська на темно-сірому опідзоленому легкосуглинковому грунті.

Схема досліду передбачала вивчення варіантів удобрення на фоні мінімальної та інтенсивної системи захисту рослин: контроль (без добрив), $\mathrm{N}_{60} \mathrm{~N}_{30}, \quad \mathrm{P}_{135} \mathrm{~K}_{135}+\mathrm{N}_{80}+\mathrm{N}_{55}$, побічна продукція, $\mathrm{P}_{90} \mathrm{~K}_{90}+\mathrm{N}_{60}+\mathrm{N}_{30}$.

У досліді вивчали технологію з інтенсивним захистом рослин, що включало використання пестицидів: «Амістар Екстра», 0,5 л/га, «Карате Зеон», 0,2 л/га, «Альто Супер», 0,5 л/га, «Лінтур», 0,15 г/га, а також мінімальним, де застосовували лише протруювач - «Максим Стар», 1,5 л/т.

Облікова площа ділянки - $25 \mathrm{~m}^{2}$, повторність дослідів - чотириразова, розміщення ділянок рендомізоване. Попередником був горох. Агро- 


\section{СІЛЬСЬКЕ ГОСПОДАРСТВО. РОСЛИННИЦТВО}

техніка загально прийнята для даної грунтовокліматичної зони.

Грунт - темно-сірий опідзолений легкосуглинковий на лесовидному суглинку 3 наступною характеристикою основних агрохімічних показників: $\mathrm{pH}$ сол $-5,2$, гідролітична кислотність 39 мг-екв/кг грунту, вміст загального гумусу 2,0 \% (за Тюріним і Кононовою), азоту, що легко гідролізується (за Корнфілдом) - 54-66 мг/кг грунту,рухомого фосфору - 160 мг/кг грунту (за Чіріковим), обмінного калію - 140 мг/кг грунту (за Чіріковим).

Вміст важких металів визначали в зразках, зерні та грунті, який відбирали 3 орного шару (020) одночасно 3 рослинними зразками. Рухомі форми важких металів із грунту вилучали за допомогою екстракції 1 н НCI, а їх кількісне визначення проводили атомно-адсорбційним методом [6].

Екологічний стан
незадовільний
задовільний
нормальний
оптимальний

Технології оцінювали за впливом на стан агроекосистеми:

Статистичну обробку результатів проводили за допомогою дисперсійного і регресійного аналізів.

Результати досліджень. Екологічну експертизу технологій вирощування озимої пшениці здійснювали за методикою екологічної експертизи технологій вирощування сільськогосподарських культур [2].

Оцінку технологій за впливом на показники родючості грунту проводили шляхом порівняння фактичного стану 3 еталонним (табл. 1). Еталоном $€$ грунт 3 оптимальними показниками родючості, згідно 3 нормативними документами (ДСТУ 4362:2004) [8].

Згідно 3 таким порівнянням було проведено екологічне оцінювання технології застосування агрохімікатів за впливом на стан темно-сірого опідзоленого грунту на фоні інтенсивного і мінімального захисту (табл. 2).
Відхилення від оптимуму в бік погіршення перевищує $25 \%$
Бал
понад $10 \%$, але не перевищує $25 \%$
0
не перевищує $10 \%$
1
не спостерігається

1. Оцінювання придатності грунту для вирощування пшениці озимої

\begin{tabular}{|c|c|c|}
\hline Екологічний стан & Показник стану грунту & Оцінка, бали \\
\hline \multicolumn{3}{|c|}{ вміст гумусу } \\
\hline Незадовільний & $<3,0$ & 0 \\
\hline Задовільний & $3,0-3,5$ & 1 \\
\hline Нормальний & $3,6-3,9$ & 2 \\
\hline Оптимальний & $\geq 4,0$ & 3 \\
\hline \multicolumn{3}{|c|}{ вміст азоту, що легко гідролізується } \\
\hline Незадовільний & $<64$ & 0 \\
\hline Задовільний & $64-76$ & 1 \\
\hline Нормальний & $77-84$ & 2 \\
\hline Оптимальний & $\geq 85$ & 3 \\
\hline \multicolumn{3}{|c|}{ вміст рухомого фосфору } \\
\hline Незадовільний & $<109$ & 0 \\
\hline Задовільний & $109-130$ & 1 \\
\hline Нормальний & $131-144$ & 2 \\
\hline Оптимальний & $\geq 145$ & 3 \\
\hline \multicolumn{3}{|c|}{ вміст калію } \\
\hline Незадовільний & $<109$ & 0 \\
\hline Задовільний & $109-130$ & 1 \\
\hline Нормальний & $131-144$ & 2 \\
\hline Оптимальний & $\geq 145$ & 3 \\
\hline \multicolumn{3}{|c|}{ реакція грунтового розчину } \\
\hline Незадовільний & $<4,3$ & 0 \\
\hline Задовільний & $4,3-5,0$ & 1 \\
\hline Нормальний & $5,1-5,6$ & 2 \\
\hline Оптимальний & 5,7 & 3 \\
\hline
\end{tabular}


СІЛЬСЬКЕ ГОСПОДАРСТВО. РОСЛИННИЦТВО

\section{2. Екологічне оцінювання стану темно-сірого опідзоленого трунту щодо вимог вирощування пшениці озимої до родючості}

\begin{tabular}{|c|c|c|c|}
\hline Екологічний стан & $\begin{array}{c}\text { Показник стану } \\
\text { грунту }\end{array}$ & Екологічний стан & Оцінка, бали \\
\hline \multicolumn{4}{|c|}{ вміст гумусу } \\
\hline Контроль & $2,2 * / 2,4 * *$ & незадовільний/незадовільний & $0 / 0$ \\
\hline $\mathrm{N}_{60} \mathrm{~N}_{30}$ & $2,6 / 2,4$ & незадовільний/незадовільний & $0 / 0$ \\
\hline $\mathrm{P}_{135} \mathrm{~K}_{135}+\mathrm{N}_{80}+\mathrm{N}_{55}$ & $2,9 / 2,2$ & незадовільний/незадовільний & $0 / 0$ \\
\hline побічна продукція & $2,5 / 2,2$ & незадовільний/незадовільний & $0 / 0$ \\
\hline $\mathrm{P}_{90} \mathrm{~K}_{90}+\mathrm{N}_{60}+\mathrm{N}_{30}$ & $2,5 / 2,3$ & незадовільний/незадовільний & $0 / 0$ \\
\hline \multicolumn{4}{|c|}{ вміст азоту, що легко гідролізується } \\
\hline Контроль & $77 / 72$ & нормальний/задовільний & $2 / 1$ \\
\hline $\mathrm{N}_{60} \mathrm{~N}_{30}$ & $74 / 74$ & задовільний/задовільний & $1 / 1$ \\
\hline $\mathrm{P}_{135} \mathrm{~K}_{135}+\mathrm{N}_{80}+\mathrm{N}_{55}$ & $88 / 81$ & оптимальний/нормальний & $3 / 2$ \\
\hline побічна продукція & $77 / 74$ & нормальний/задовільний & $2 / 1$ \\
\hline $\mathrm{P}_{90} \mathrm{~K}_{90}+\mathrm{N}_{60}+\mathrm{N}_{30}$ & $89 / 75$ & оптимальний/задовільний & $2 / 1$ \\
\hline \multicolumn{4}{|c|}{ вміст рухомого фосфору } \\
\hline Контроль & $81 / 75$ & незадовільний/незадовільний & $0 / 0$ \\
\hline $\mathrm{N}_{60} \mathrm{~N}_{30}$ & $110 / 127$ & задовільний/задовільний & $1 / 1$ \\
\hline $\mathrm{P}_{135} \mathrm{~K}_{135}+\mathrm{N}_{80}+\mathrm{N}_{55}$ & $173 / 196$ & оптимальний/оптимальний & $3 / 3$ \\
\hline побічна продукція & $148 / 137$ & оптимальний/нормальний & $3 / 2$ \\
\hline $\mathrm{P}_{90} \mathrm{~K}_{90}+\mathrm{N}_{60}+\mathrm{N}_{30}$ & $241 / 228$ & оптимальний/оптимальний & $3 / 3$ \\
\hline \multicolumn{4}{|c|}{ вміст обмінного калію } \\
\hline Контроль & $69 / 64$ & незадовільний/незадовільний & $0 / 0$ \\
\hline $\mathrm{N}_{60} \mathrm{~N}_{30}$ & $138 / 134$ & нормальний/нормальний & $2 / 2$ \\
\hline $\mathrm{P}_{135} \mathrm{~K}_{135}+\mathrm{N}_{80}+\mathrm{N}_{55}$ & $162 / 141$ & оптимальний/нормальний & $3 / 2$ \\
\hline побічна продукція & $153 / 125$ & оптимальний/задовільний & $3 / 1$ \\
\hline $\mathrm{P}_{90} \mathrm{~K}_{90}+\mathrm{N}_{60}+\mathrm{N}_{30}$ & $224 / 204$ & оптимальний/оптимальний & $3 / 3$ \\
\hline \multicolumn{4}{|c|}{ реакція грунтового розчину } \\
\hline Контроль & $6,6 / 6,7$ & оптимальний/оптимальний & $3 / 3$ \\
\hline $\mathrm{N}_{60} \mathrm{~N}_{30}$ & $6,8 / 6,2$ & оптимальний/оптимальний & $3 / 3$ \\
\hline $\mathrm{P}_{135} \mathrm{~K}_{135}+\mathrm{N}_{80}+\mathrm{N}_{55}$ & $6,0 / 6,3$ & оптимальний//оптимальний & $3 / 3$ \\
\hline побічна продукція & $6,7 / 6,5$ & оптимальний/оптимальний & $3 / 3$ \\
\hline $\mathrm{P}_{90} \mathrm{~K}_{90}+\mathrm{N}_{60}+\mathrm{N}_{30}$ & $6,0 / 6,2$ & оптимальний/оптимальний & $3 / 3$ \\
\hline
\end{tabular}

Примітки: ${ }^{*}$ - інтенсивний захист, ** - мінімальний захист

Отримані результати показали, що всі технології на фоні інтенсивного і мінімального захисту за вмістом гумусу призводять до незадовільного екологічного стану; за вмістом азоту, що легко гідролізується на обох фонах спостерігається оптимальний і нормальний екологічний стан; за вмістом рухомого фосфору і обмінного калію дані технології забезпечують оптимальний, нормальний, задовільний екологічний стан.

Було проведено екологічну експертизу технологій вирощування озимої пшениці за впливом на процеси міграції важких металів у генетичних горизонтах грунту.

Розподіл важких металів за генетичними горизонтами грунту визначається процесами грунтоутворення і мінералогічним складом материнських порід [3]. Також рівень вмісту важких мета- лів залежить від гранулометричного складу i вмісту органічної речовини [5].

Екологічну експертизу проводили за коефіцієнтом концентрації у різних генетичних горизонтах грунту, який характеризує ступінь накопичення елементів (важких металів) у грунті відносно контролю:

$$
\mathrm{Kc}=\mathrm{k}_{\mathrm{i}} / \mathrm{K} \mathrm{i},
$$

$\mathrm{k}_{\mathrm{i}}$ - вміст i-хімічного елементу у n-компоненті, К і - вміст і-хімічного елементу в еталоні (контролі).

Величина коефіцієнту концентрації свідчить про активність процесів вилуговування $(\mathrm{Kc}<1) \mathrm{i}$ накопичення $(\mathrm{Kc}>1)$ катіонів у генетичних горизонтах грунту. За величиною концентрації існує наступна градація (табл. 3). 


\section{СІЛЬСЬКЕ ГОСПОДАРСТВО. РОСЛИННИЦТВО}

Дослідження впливу мінеральних і органічних добрив за мінімального й інтенсивного захисту рослин на накопичення в грунті свинцю і міді, показали, що внесення добрив протягом трива- лого часу не супроводжуються значним зростанням вмісту їх у темно-сірому опідзоленому грунті (рис. 1-4).

\section{3. Оцінка технології за коефіцієнтами концентрації [2]}

\begin{tabular}{|c|c|c|}
\hline Екологічний стан & перевищення коефіцієнту концентрації & Оцінка, бали \\
\hline незадовільний & $\geq 5,0$ & 0 \\
\hline задовільний & $3,0-5,0$ & 1 \\
\hline нормальний & $1,0-2,9$ & 2 \\
\hline оптимальний & $\leq 1,0$ & 3 \\
\hline
\end{tabular}

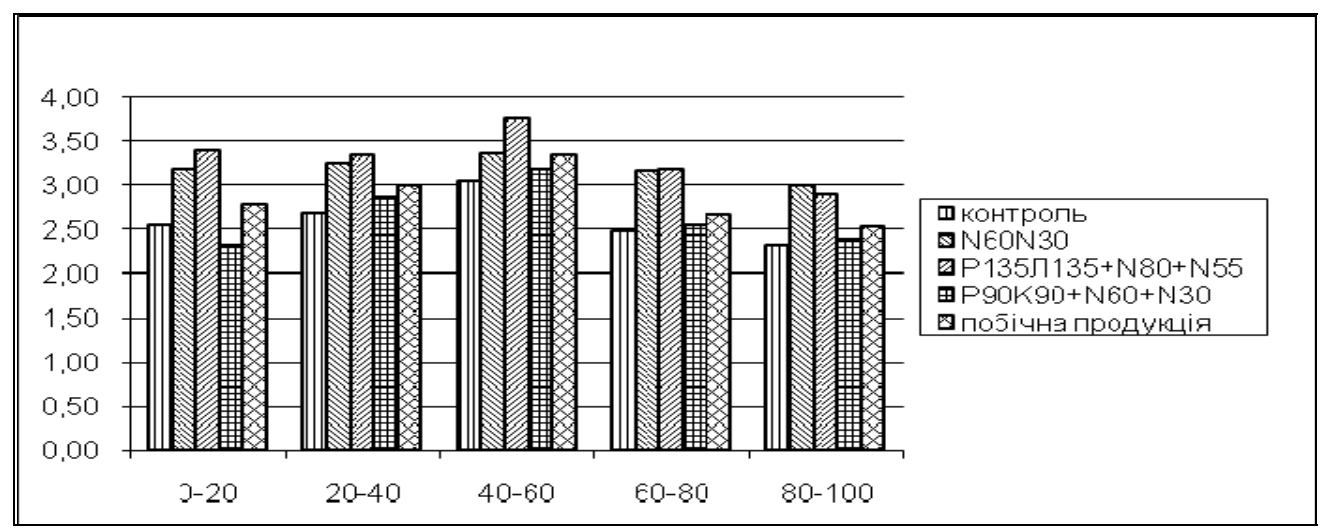

Рис. 1. Вміст РЬ по профілю темно-сірого опідзоленого трунту за інтенсивного захисту

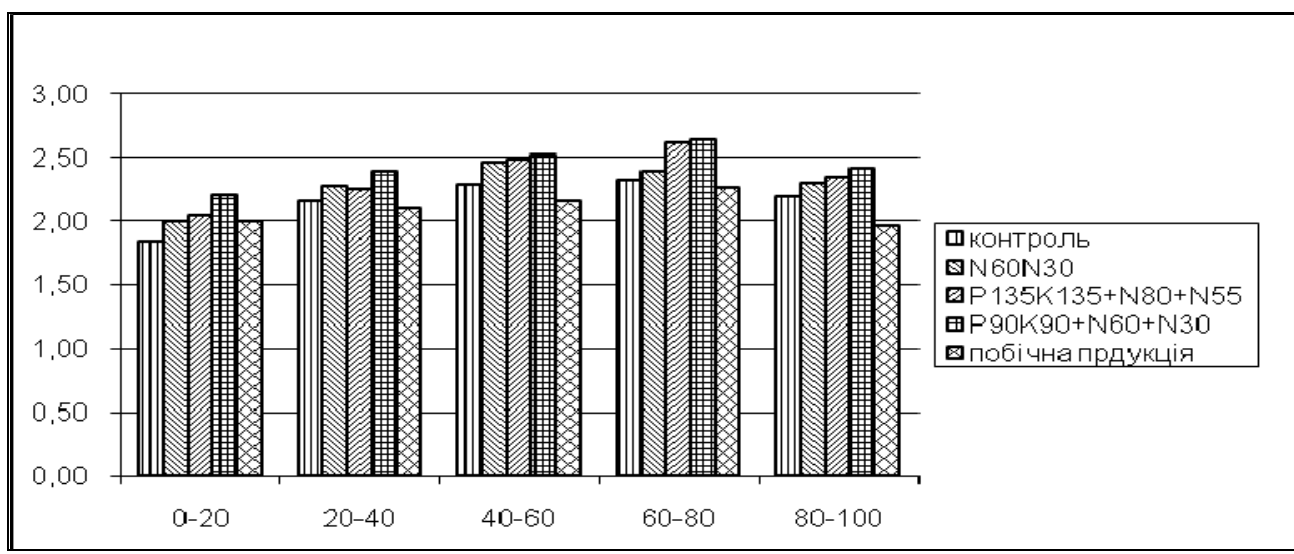

Рис. 2. Вміст РЬ по профілю темно-сірого опідзоленого трунту за мінімального захисту

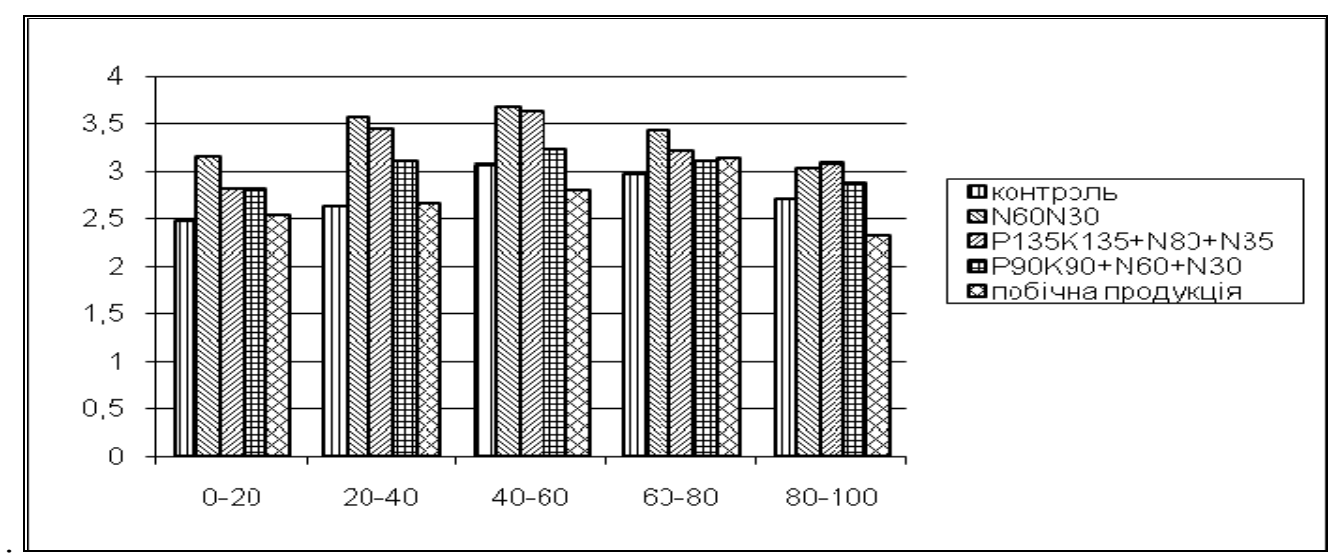

Рис. 3. Вміст Си по профілю темно-сірого опідзоленого грунту за інтенсивного захисту 


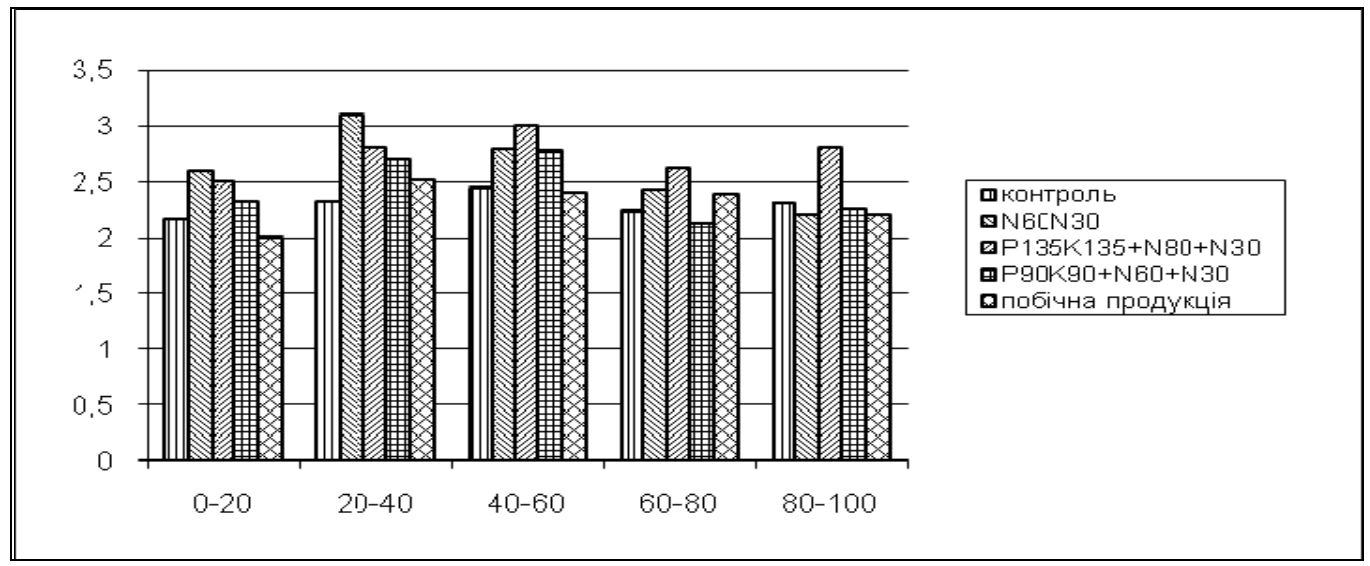

Рис. 4. Вміст Си по профілю темно-сірого опідзоленого трунту за мінімального захисту

Під час вирощування озимої пшениці вміст важких металів у шарах грунту був нерівномірним. У нижніх шарах грунту кількість їх зменшувалась, порівняно 3 верхніми шарами. У випадку застосування $\mathrm{P}_{135} \mathrm{~K}_{135}+\mathrm{N}_{80}+\mathrm{N}_{55}, \mathrm{~N}_{60} \mathrm{~N}_{30}$ відбулося збільшення свинцю і міді в шарах 20-40, 40-60 см на фоні інтенсивного захисту. На інших варіантах на фоні інтенсивного і мінімального захисту по всьому профілю грунту значного збільшення не помітно.

Було проведено екологічне оцінювання темносірого опідзоленого грунту за коефіцієнтом концентрації у випадку застосування різних технологій вирощування пшениці (табл. 4).
Отримані результати за вмістом свинцю свідчать, що у більшості випадків застосування мінеральних і органічних добрив на фоні інтенсивного і мінімального захисту не призводило до погіршення екологічного стану грунту. На варіантах $\mathrm{N}_{60} \mathrm{~N}_{30}, \mathrm{P}_{135} \mathrm{~K}_{135}+\mathrm{N}_{80}+\mathrm{N}_{55}$, на фоні інтенсивного захисту i $\mathrm{P}_{90} \mathrm{~K}_{90}+\mathrm{N}_{60}+\mathrm{N}_{30}$ за мінімального захисту спостерігається такий перерозподіл свинцю у профілі грунту, який характеризує нормальний екологічний стан. Коефіцієнт концентрації коливався в межах 1,1-1,3, що характеризує мінімальне накопичення свинцю у генетичних горизонтах даного грунту. Інші технології відповідають оптимальному екологічному стану.

\section{4. Екологічне оцінювання темно-сірого опідзоленого трунту за коефіцієнтами концентрації} свинцю і міді в разі застосування різних технологій вирощування пшениці

\begin{tabular}{|c|c|c|c|c|c|c|c|}
\hline \multirow{2}{*}{$\begin{array}{l}\text { Варіанти } \\
\text { досліду }\end{array}$} & \multicolumn{5}{|c|}{ Генетичний горизонт } & \multirow{2}{*}{$\begin{array}{c}\text { Екологічний } \\
\text { стан }\end{array}$} & \multirow{2}{*}{$\begin{array}{c}\text { Оцінка, } \\
\text { бали }\end{array}$} \\
\hline & $\mathrm{He}$ & $\mathrm{Hi}$ & IHgi & Pigl & Pkgl & & \\
\hline \multicolumn{8}{|c|}{ коефіцієнт концентрації свинцю } \\
\hline $\mathrm{N}_{60} \mathrm{~N}_{30}$ & $1,3 * / 1,0 * *$ & $1,2 / 1,0$ & $1,1 / 1,0$ & $1,2 / 1,0$ & $1,2 / 1,0$ & $\begin{array}{l}\text { нормальний/ } \\
\text { оптимальний }\end{array}$ & $2 / 3$ \\
\hline $\begin{array}{c}\mathrm{P}_{135} \mathrm{~K}_{135} \\
+\mathrm{N}_{80}+\mathrm{N}_{55}\end{array}$ & $1,3 / 1,1$ & $1,2 / 1,0$ & $1,2 / 1,0$ & $1,2 / 1,1$ & $1,2 / 1,0$ & $\begin{array}{l}\text { нормальний/ } \\
\text { оптимальний }\end{array}$ & $2 / 2$ \\
\hline $\begin{aligned} & \mathrm{P}_{90} \mathrm{~K}_{90} \\
&+ \mathrm{N}_{60}+\mathrm{N}_{30} \\
&\end{aligned}$ & $1,0 / 1,1$ & $1,0 / 1,1$ & $1,1 / 1,0$ & $1,0 / 1,1$ & $1,0 / 1,0$ & $\begin{array}{l}\text { оптимальний/ } \\
\text { нормальний }\end{array}$ & $2 / 2$ \\
\hline $\begin{array}{c}\text { побічна } \\
\text { продукція }\end{array}$ & $1,0 / 1,1$ & $1,1 / 0,9$ & $1,1 / 0,8$ & $1,0 / 0,9$ & $1,0 / 0,9$ & $\begin{array}{l}\text { оптимальний/ } \\
\text { оптимальний }\end{array}$ & $3 / 3$ \\
\hline \multicolumn{8}{|c|}{ коефіцієнт концентрації міді } \\
\hline $\mathrm{N}_{60} \mathrm{~N}_{30}$ & $1,1 / 1,1$ & $1,2 / 0,9$ & $1,2 / 1,0$ & $1,3 / 1,0$ & $1,2 / 1,0$ & $\begin{array}{l}\text { нормальний/ } \\
\text { оптимальний }\end{array}$ & $2 / 3$ \\
\hline $\begin{array}{r}\mathrm{P}_{135} \mathrm{~K}_{135} \\
+\mathrm{N}_{80}+\mathrm{N}_{55} \\
\end{array}$ & $1,2 / 1,1$ & $1,4 / 1,0$ & $1,3 / 1,1$ & $1,2 / 1,1$ & $1,2 / 1,0$ & $\begin{array}{c}\text { нормальний/ } \\
\text { нормальний }\end{array}$ & $2 / 3$ \\
\hline $\begin{aligned} & \mathrm{P}_{90} \mathrm{~K}_{90} \\
&+ \mathrm{N}_{60}+\mathrm{N}_{30} \\
&\end{aligned}$ & $1,1 / 1,1$ & $1,1 / 1,0$ & $1,0 / 1,0$ & $1,0 / 1,0$ & $1,0 / 1,0$ & $\begin{array}{l}\text { оптимальний/ } \\
\text { оптимальний }\end{array}$ & $3 / 3$ \\
\hline $\begin{array}{c}\text { побічна } \\
\text { продукція }\end{array}$ & $1,1 / 0,9$ & $1,0 / 1,0$ & $0,9 / 0,9$ & $1,0 / 1,0$ & $0,9 / 0,9$ & $\begin{array}{l}\text { оптимальний/ } \\
\text { оптимальний }\end{array}$ & $2 / 3$ \\
\hline
\end{tabular}

Примітки: * - інтенсивний захист, ** - мінімальний захист 


\section{СІЛЬСЬКЕ ГОСПОДАРСТВО. РОСЛИННИЦТВО}

Екологічне оцінювання темно сірого опідзоленого грунту за коефіцієнтом концентрації міді показало, що $\mathrm{N}_{60} \mathrm{~N}_{30}, \mathrm{P}_{135} \mathrm{~K}_{135}+\mathrm{N}_{80}+\mathrm{N}_{55}$ на фоні інтенсивного захисту і $\mathrm{P}_{135} \mathrm{~K}_{135}+\mathrm{N}_{80}+\mathrm{N}_{55}$ на фоні мінімального захисту відповідали нормальному екологічному стану, коефіцієнт концентрації яких коливався в межах 1,1-1,5. Це свідчить про те, що відбувалося незначне накопичення міді у генетичних горизонтах темно-сірого опідзолено-

$$
\mathrm{EO}=\sum^{-\mathrm{n}_{2}+\mathrm{n}_{3}+, \ldots+, \mathrm{n}_{\mathrm{n}}} \frac{\mathrm{n}}{\mathrm{n}},
$$

го грунту. Більшість варіантів на обох фонах відповідала оптимальному екологічному стану.

Врахування всіх показників, що вивчалися під час випробування технологій, дало змогу провести комплексне оцінювання і встановити ступінь технологічних процесів (табл. 5). Екологічне оцінювання (ЕО) технології за комплексом показників проводили за рівнянням

де $\mathrm{n}_{\mathrm{n}}$ - показник, згідно з яким проводили оцінювання, бал;

$\mathrm{n}$ - кількість показників, за якими проводили оцінювання.

Згідно з методичними рекомендаціями [2] пропонуємо таку градацію технологій за досконалістю:

I

II

III 2, 2,5-2,9 балів

IV $\quad 3$ бали технологія недосконала і не може бути рекомендована виробництву

технологія перед впровадженням у виробництво потребує істотного вдосконалення

потребують вдосконалення окремі технологічні операції технологія досконала і може бути рекомендована виробництву

\section{5. Комплексне екологічне оцінювання технологій вирощування пшениці озимої} в зоні північного Лісостепу Украйни

\begin{tabular}{|l|c|c|}
\hline \multirow{2}{*}{ Варіанти досліду } & \multicolumn{2}{|c|}{ Система захисту рослин } \\
\cline { 2 - 3 } & інтенсивна & мінімальна \\
\hline 1. Контроль & 1,8 & 1,4 \\
\hline $2 . \mathrm{N}_{60} \mathrm{~N}_{30}$ & 1,5 & 1,8 \\
\hline 3. $\mathrm{P}_{135} \mathrm{~K}_{135}+\mathrm{N}_{80}+\mathrm{N}_{55}$ & 2,2 & 2,2 \\
\hline 4. Побічна продукція & 2,5 & 2,0 \\
\hline 5. $\mathrm{P}_{90} \mathrm{~K}_{90}+\mathrm{N}_{60}+\mathrm{N}_{30}$ & 2,5 & 2,2 \\
\hline
\end{tabular}

Результати екологічного оцінювання технологій вирощування озимої пшениці за показниками родючості і міграції важких металів у генетичних горизонтах темно-сірого опідзоленого грунту показали, що технології, які передбачають інтенсивний захист рослин та удобрення $\mathrm{P}_{90} \mathrm{~K}_{90}+\mathrm{N}_{60}+\mathrm{N}_{30}$ і побічну продукцію потребують вдосконалення за деякими технологічними операціями, а технології, які передбачають застосування $\mathrm{N}_{60} \mathrm{~N}_{30}$ і $\mathrm{P}_{135} \mathrm{~K}_{135}+\mathrm{N}_{80}+\mathrm{N}_{55}$ перед впровадженням потребують істотного вдосконалення. Всі технології, що передбачають застосування добрив на фоні мінімального захисту рослин потребують подальшого вдосконалення, оскільки не забезпечують оптимального агрохімічного стану темно-сірого опідзоленого грунту.

Висновок. Отримані дані свідчать, що екологічна експертиза технологій вирощування озимої пшениці в умовах північного Лісостепу України за агрохімічними показниками грунту повинна передбачити таке внесення добрив, щоб забезпечити оптимальні параметри родючості грунту. Використання коефіцієнта концентрації для характеристики екологічного стану темно-сірого опідзоленого грунту за показниками нагромадження і вилуговування важких металів у генетичних горизонтах дає можливість оцінити технології застосування добрив, засобів захисту і за необхідності провести відповідні вдосконалення.

Перспективи нашої наукової роботи в подальшому будуть направлені на вивчення впливу окремих технологічних операцій на якість бобових і технічних культур та проведення екологічної оцінки технологій вирощування сої і ріпаку за біохімічними, токсикологічними, санітарногігієнічними показниками. 


\section{БІБЛІОГРАФІЯ}

1. Говорина В. В. Содержание и распределение кадмия, свинца и никеля в растениях яровой пшеницы в зависимости от уровня минерального питания и загрязнения тяжелыми металлами / В. В. Говорина, Н. Г. Ракинов, Лин Кео Сопхеак, Н. К. Сидоренкова // Агрохимия. - 2007. - №3. C. 61-67.

2. Екологічна експертиза технологій вирощування сільськогосподарських культур (методичні рекомендації) / [Макаренко Н. А., Бондарь В. I., Макаренко В. В. та ін.] ; за ред. Н. А. Макаренко, В. В. Макаренко. - К. : ДІА, 2008. - 84 с.

3. Жигарева Т. Л. Влияние природных мелиорантов и тяжелых металлов на урожайность зерновых культур и микрофлору дерновоподзолистой почвы / Т. Л. Жигарева, Р. М. Алексахин, Д. Г. Свириденко // Агрохимия. - 2005. №11. - С. 60-65.

4. Макаренко Н. А. Агроекологічна оцінка мінеральних добрив за впливом на грунтову сис- тему: автореф. дис. д. с.-г. н. : 03.00.16. / Наталія Анатоліївна Макаренко. - К., 2002. - 37 с.

5. Макаренко Н. А. Екологічна експертиза технологій вирощування сільськогосподарських культур / Н. А. Макаренко, В. І. Бондар, В. В. Макаренко // Агроекологічний журнал. 2008. - Спеціальний випуск. - С. 14-18.

6. Методические указания по определению тяжелых металлов в почвах сельскохозяйственных угодий и продукции растениеводства / ЦИНАО. - М. : ЦИНАО, 1992. - 61 с.

7. Популан М. I. Родючість грунту як природно-антропогенна його властивість, її види та параметрична оцінка / М. І. Популан, В. А. Величко, В. Б. Соловей // Вісник аграрної науки. 2009. - №2. - C. 17-24.

8. Якість грунту. Показники родючості грунтів : ДСТУ 4362:2006. - [Чинний від 2006-01-01]. - К. : Держспоживстандарт України, 2006. - 40 с. - (Національний стандарт України). 